\title{
PREDIKSI PENJUALAN SEPEDA MOTOR HONDA MENGGUNAKAN JARINGAN SYARAF TIRUAN
}

\author{
Tri Waluyo ${ }^{1)}$, Arief Hermawan ${ }^{2)}$, Adityo Permana Wibowo ${ }^{3)}$ \\ ${ }^{1,2}$ Magister Teknologi Informasi Universitas Teknologi Yogyakarta \\ ${ }^{3}$ Program Studi Teknik Informatika, Universitas Teknologi Yogyakarta \\ email : triwaluyo@student.uty.ac.id ${ }^{l)}$, ariefdb@staff.uty.ac.id ${ }^{21}$, adityopw@staff.uty.ac.id ${ }^{3)}$
}

\begin{abstract}
Abstraksi
Prediksi penjualan merupakan salah satu cara untuk meningkatkan laba perusahaan. Peramalan dipergunakan untuk menyeterakan antara perbedaan waktu yang sekarang dan yang akan datang terhadap kebutuhan. Jaringan Syaraf Tiruan (JST) dapat mengaplikasikan dengan baik metode peramalan. Data yang diperoleh dibagi menjadi data pelatihan dan pengujian. Dengan menggunakan berbagai operator di software Rapidminer diperoleh hasil Root Mean Square Error (RMSE) terendah yaitu 45327.969 windowing 12, yang artinya data 12 bulan pertama adalah data yang krusial atau penting sebagai acuan untuk meramalkan/memprediksi penjualan sepeda motor Honda. Perusahaan dapat memprediksi jumlah permintaan konsumen terhadap produk pada tahun berikutnya, selanjutnya ditindaklanjuti ke bagian produksi.
\end{abstract}

Kata Kunci: Prediksi, Penjualan Sepeda Motor, Jaringan Syaraf Tiruan, Root Mean Square Error (RMSE)

\section{Pendahuluan}

Dewasa ini transportasi menjadi salah satu elemen yang sangat membantu mobilitas manusia dalam menjalankan kegiatan sehari-hari. Pertumbuhan penduduk indonesia yang meningkat juga mempengarui bertambahnya jumlah kendaraan bermotor yang ada di Indonesia. Salah satu kendaraan bermotor yang paling diminati adalah kendaraan roda dua atau sepeda motor, salah satu alasannya karena bisa menghindari kemacetan jalan yang semakin parah.

Berdasarkan data dari Badan Pusat Statistik (BPS) tahun 2014, pada tahun 2011 jumlah pemilik kendaraan bermotor di Indonesia sebesar 85.601.351 unit dan angka tersebut semakin melonjak pada tahun 2012 yakni sebesar 94.373.324 unit. Masyarakat lebih tertarik untuk membeli sepeda motor dengan alasan infrastruktur yang belum baik ataupun karena harga yang lebih terjangkau dari pada membeli mobil. Dengan sepeda motor, resiko terjebak macet bisa dikurangi dan lebih leluasa melintas dijalan-jalan yang kondisinya rusak (Sholikhah, 2011).

Menurut penelitian yang pernah dilakukan oleh (Paruntu \& Palandeng, 2018), banyak faktor yang mempengaruhi tinggi rendahnya tingkat penjualan sepeda motor diantaranya produk itu sendiri, harga, distribusi, promosi dan layanan purna jual. Prakiraan penjualan yang tepat dapat dijadikan rujukan guna menentukan keberlangsungan usaha dan tingkat keuntungan yang dicapai. Sebagai contoh, jumlah persediaan akhir sepeda motor Suzuki secara keseluruhan tersisa 1104 unit atau jka dirata-rata hanya sekitar 61 produk saja yang terjual tiap bulannya. Hal ini menjadi salah satu faktor masalah bagi perusahaan, karena jika terus-menerus seperti ini maka perusahaan dapat mengalami kerugian.

Berdasarkan permasalahan diatas dan beberapa penjelasan tentang penelitian yang menggunakan JST, maka penelitian ini akan menggunakan Jaringan Syaraf Tiruan untuk melakukan prediksi penjualan sepeda motor, khususnya Merk Honda. Data yang digunakan merupakan data penjualan sepeda motor Honda dari tahun 2005 s/d tahun 2018. Harapannya penelitian ini bisa bermanfaat bagi perusahaan sebagai pertimbangan untuk melakukan produksi sepeda motor Honda.

\section{Tinjauan Pustaka}

\section{Penelitian terdahulu}

Penelitian yang menggunakan Jaringan Syaraf Tiruan (JST) itu sendiri sudah banyak dilakukan, antara lain adalah penelitian (Fachrie \& Wibowo, 2018) yang membahas tentang penggunaan JST untuk mengklasifikasi kinerja satpam. Klasifikasi kinerja berdasarkan pemrosesan 10 variabel input dan 3 variabel output. Penelitian tersebut menggunakan JST Multi Layer Perceptron. Dengan menggunakan Teknik Cross Validation sebanyak 10 fold, menghasilkan nilai akurasi sebesar 97,75\% dengan menggunakan 2 hidden layer.

Penelitian lain yang menggunakan JST juga pernah dilakukan oleh (Wibisono \& Hermawan, 2019). Penelitian tersebut membahas tentang penggunaan JST untuk menentukan faktor-faktor penentu penyakit kanker payudara. Menggunakan 10 variabel input dan 2 variabel output serta menggunakan 2 hidden layer. Dari penelitian 
tersebut menghasilkan variabel yang berpengaruh dan tidak berpengaruh untuk penentu penyakit kanker payudara. Variabel paling berpengaruh adalah usia, sedangkan variabel yang tidak berpengaruh adalah MCP-1.

Jaringan Syaraf Tiruan juga dapat digunakan untuk memprediksi penjualan bahan kimia Hydrated Lime. Hydrate Lime merupakan salah satu bahan kimia campuran untuk pembuatan kertas. Penerapan Neural Network (JST) dapat meningkatkan nilai terkecil rata-rata nilai Root Means Square Error (RMSE) dalam prediksi penjualan Hydrate Lime pada PT. Kemindo International (Wahyuni, 2017).

Selain itu, (Widyatmoko, Honggowibowo, \& Retnowati, 2012) pernah melakukan penelitian tentang prediksi penjualan di minimarket menggunakan metode Time Series. Dengan menggunakan perhitungan exponential smoothing dan moving average dicari nilai MAD (Mean Absolute Deviation) atau peramalan, dimana nilai MAD yang terkecil dari perhitungan exponential smoothing dan moving average merupakan hasil peramalan dengan kesalahan yang kecil. Hasil peramalan tidak akan selalu tepat, karena dipengaruhi beberapa faktor permintaan di pasar.

Jaringan Syaraf Tiruan juga dapat diaplikasikan untuk peramalan penjualan mobil. Pendekatan peramalan kuantitatif dengan metode time series akan menentukan nilai data masukan dari sekumpulan data serial atau berkala dari transaksi pada suatu jangka waktu tertentu. Data dibagi menjadi data pelatihan, data pengujian dan validasi. Proses peramalan menggunakan metode Certainty Factor (CF) sebagai nilai pembanding pada bobot koreksi yang telah dilatih menggunakan Jaringan Syaraf Tiruan backpropagation untuk prediksi yang optimal. Simulai program peramalan penjualan mobil pada tahun 2015 dengan variabel input data penjualan daerah 30.000 unit, penjualan dealer 25.000 unit, penjualan tunai 25.000 unit, $\mathrm{CF}=0.5$ dan kredit 19.000 menghasilkan ramalan penjualan sebanyak 29579 unit dengan target error 4,205\% (Pakaja, Naba, \& Purwanto, 2012).

\section{Jaringan Syaraf Tiruan}

Jaringan Syaraf Tiruan (Artificial Neural Network) atau disingkat JST adalah sistem komputasi dengan arsitektur dan operasinya diilhami dari pengetahuan sel syaraf biologi di dalam otak. JST dapat digambarkan sebagai model matematis dan komputasi untuk fungsi aproksimasi nonlinier, klasifikasi data, cluster dan regresi nonparametric atau sebagai sebuah simulasi dari koleksi model syaraf biologi (Dristyan, 2018).

\section{Metode Penelitian}

Untuk mencapai tujuan dari penelitian ini maka perlu dilakukan langkah-langkah sebagai berikut:

1. Menyiapkan data

Dataset yang digunakan pada penelitian ini adalah data penjualan sepeda motor dari tahun 2005 s/d 2018 (Triatmono, 2018). Data tersebut sesuai dengan data yang dikeluarkan oleh Asosiasi Industri Sepeda Motor Indonesia (AISI) di situs resminya https://www.aisi.or.id/statistic/.

2. Dari dataset tersebut, penulis kemudian melakukan filtering data, yaitu hanya mengambil dataset untuk penjualan motor Merk Honda, dikarenakan jumlahnya yang sangat banyak.

3. Setelah dilakukan filtering, selanjutnya dipilih data yang nantinya digunakan sebagai Data Pelatihan dan Data Pengujian. Jumlah seluruh data yang digunakan dalam penelitian ini adalah 168 data dengan komposisi 113 data digunakan sebagai data pelatihan dan 48 data digunakan sebagai data pengujian.

4. Setelah data siap, selanjutnya dilakukan pemrosesan data dengan menggunakan aplikasi bantuan Rapidminer seri 9.2.

Dataset yang digunakan berbasis file dengan ekstensi .xls sehingga pada aplikasi rapidminer menggunakan komponen Read Excel. Kemudian komponen lain yang digunakan adalah Optimize Parameter. Komponen Optimize Parameter digunakan untuk mengetahui variabel/parameter mana yang paling berpengaruh dalam memprediksi penjualan motor. Tampilan hubungan komponen tersebut seperti terlihat pada Gambar 1 .

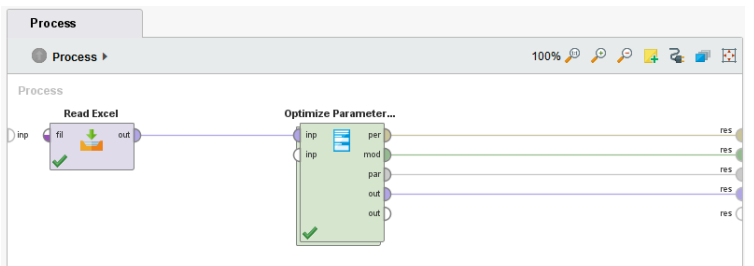

Gambar 1. Komponen yang digunakan pada Rapidminer

Pada komponen Optimize Parameter diperlukan parameter lain yang mendukung proses pengolahan data. Komponen tersebut antara lain Windowing, Split Data, Neural Network, Apply Model, Performance. Masing-masing komponen tersebut digunakan untuk proses perhitungan yang akan dilakukan. Diantaranya untuk mencari nilai Root Means Square Error (RMSE) yang berpengaruh dari windowing. Penggunaan komponen yang ada didalam Optimize Parameter seperti terlihat pada Gambar 2. 


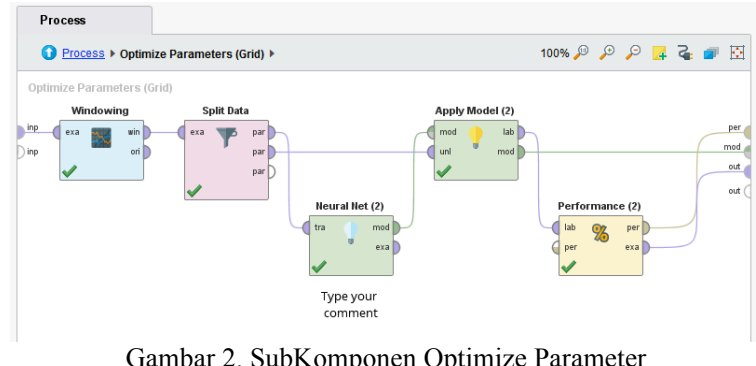

Gambar 2. SubKomponen Optimize Parameter

Setelah dilakukan pemrosesan dengan komponen dan operator yang sudah dujabarkan diatas, menghasilkan beberapa poin, antara lain, arsitektur JST yang menunjukkan bahwa terdapat 12 node layer input, 3 node hidden layer dan 1 node output layer. Komposisi layer tersebut merupakan komposisi terbaik yang menghasilkan RMSE terkecil. Seperti terlihat pada Gambar 3.

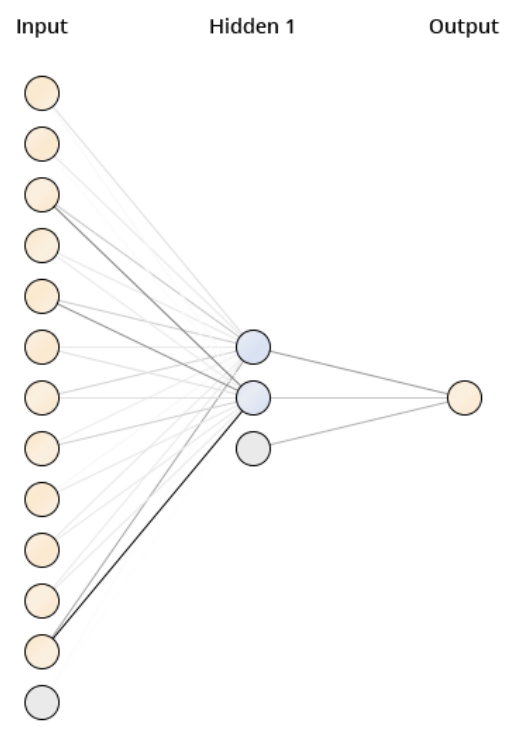

Gambar 3. Arsitektur JST

\section{Hasil dan Pembahasan}

Berdasarkan pemrosesan yang sudah dilakukan menggunakan Aplikasi Rapidminer, menunjukkan beberapa hasil, antara lain mulai dari penggunaan operator Windowing. Windows size diperoleh nilai Root Means Square Error (RMSE) terkecil adalah 76762.226 pada Windowing 7, seperti terlihat pada Gambar 4.

Optimize Parameters (Grid) (6 rows, 3 columns)
\begin{tabular}{|l|l|l|}
\hline iteration & Windowing.window_size & root_mean_squared_... \\
\hline 1 & 5 & 77752.673 \\
\hline 2 & 7 & 76762.226 \\
\hline 3 & 9 & 114662.778 \\
\hline 4 & 11 & 145706.736 \\
\hline 5 & 10 & 119019.120 \\
\hline 6 & 12 & 139773.584 \\
\hline
\end{tabular}

Gambar 4. Optimasi Parameter dengan Windowing
Berdasarkan hasil yang didapat dari tabel 1, terlihat bahwa nilai RMSE masih tinggi. Pengujian selanjutnya yaitu dengan melakukan optimalisasi di training cycles. Dengan memasukkan beberapa angka percobaan training cycles sehingga terdapat 2 paramater dan 30 pilihan kombinasi, maka didapat nilai RMSE terkecil yaitu pada nilai windowing $=7$ dan training cycles $=550$ dengan hasil RMSE sebesar 59857.934, seperti terlihat pada Gambar 5.

Optimize Parameters (Grid) (30 rows, 4 columns)
\begin{tabular}{|l|l|l|l|}
\hline iteration & Windowing.window_size & Neural Net (2).training_cycles & root_mean_squared... $\uparrow$ \\
\hline 8 & 7 & 550 & 59857.934 \\
\hline 29 & 10 & 700 & 64234.271 \\
\hline 2 & 7 & 500 & 66525.313 \\
\hline 17 & 10 & 600 & 73164.502 \\
\hline 16 & 11 & 600 & 74546.856 \\
\hline 24 & 12 & 650 & 75409.315 \\
\hline 30 & 12 & 700 & 75475.587 \\
\hline 15 & 9 & 600 & 75829.973 \\
\hline 1 & 5 & 500 & 79794.219 \\
\hline 7 & 5 & 550 & 81484.217 \\
\hline 12 & 12 & 550 & 83158.904 \\
\hline 11 & 10 & 550 & 83450.384 \\
\hline 27 & 9 & 700 & 83593.377 \\
\hline 28 & 11 & 700 & 84887.830 \\
\hline 19 & 5 & 650 & 85697.852 \\
\hline$\cdots$ & - & $\ldots \ldots$ & $\ldots \ldots \ldots \ldots$ \\
\hline
\end{tabular}

Gambar 5. Optimasi Parameter dengan Windowing dan Training Cycles

Berdasarkan Gambar 5, nilai RMSE sudah rendah namun masih bisa dioptimalkan lagi dengan melakukan pengubahan pada parameter Learning Rate. Pengubahan paramaternya adalah pada angka $0.01,0.02$ dan 0.03 . Sehingga terdapat 3 parameter dan 90 kombinasi pilihan. Hasilnya seperti terlihat pada Gambar 6.

\begin{tabular}{|c|c|c|c|c|}
\hline iteration & Windowing,wi... & Neural Net (2).training_cycles & Neural Net (2).learning_rate & root_mean_squared... $\uparrow$ \\
\hline 2 & 7 & 500 & 0.010 & 50217.560 \\
\hline 16 & 11 & 600 & 0.010 & 50775.540 \\
\hline 17 & 10 & 600 & 0.010 & 51087.087 \\
\hline 13 & 5 & 800 & 0.010 & 51678.377 \\
\hline 33 & 9 & 500 & 0.020 & 52154.373 \\
\hline 1 & 5 & 500 & 0.010 & 52592.317 \\
\hline 25 & 5 & 700 & 0.010 & 54425.906 \\
\hline 8 & 7 & 550 & 0.010 & 56521.522 \\
\hline 23 & 10 & 650 & 0.010 & 56573.230 \\
\hline 12 & 12 & 550 & 0.010 & 56679.666 \\
\hline 14 & 7 & 600 & 0.010 & 56974.836 \\
\hline 21 & 9 & 650 & 0.010 & 58455.543 \\
\hline 15 & 9 & 600 & 0.010 & 59465.663 \\
\hline 11 & 10 & 550 & 0.010 & 60343.409 \\
\hline 24 & 12 & 650 & 0.010 & 60766.222 \\
\hline
\end{tabular}

Gambar 6. Optimasi Parameter dengan Windowing, Training Cycles dan Learning Rate

Seperti terlihat Gambar 6, menunjukkan bahwa nilai RMSE terkecil adalah 50217.560, pada Windowing=7, Training Cycles $=500$ dan Learning Rate $=0.10$

Percobaan berikutnya untuk mengoptimalkan RMSE adalah dengan merubah Hidden Layer pada operator 
Neural Network. Hasil terkecil dari pengoptimalan Hidden Layer adalah seperti terlihat pada Gambar 7.

\begin{tabular}{|c|c|c|c|c|}
\hline iteration & Windowing,window_size & Neural Net (2), Iraining__ycles & Neural Net (2).learring_rate & root_mean__qua... $\uparrow$ \\
\hline 12 & 12 & 550 & 0.010 & 45327.969 \\
\hline 2 & 7 & 500 & 0.010 & 46838.467 \\
\hline 13 & 5 & 600 & 0.010 & 51557.531 \\
\hline 35 & 10 & 500 & 0.020 & 51622816 \\
\hline 49 & 5 & 650 & 0.020 & 52230.061 \\
\hline 4 & 11 & 500 & 0.010 & 52238.405 \\
\hline 42 & 12 & 550 & 0.020 & 52777.496 \\
\hline 14 & 7 & 600 & 0.010 & 52834.972 \\
\hline 1 & 5 & 500 & 0.010 & 53111.040 \\
\hline 36 & 12 & 500 & 0.020 & 53885.156 \\
\hline 40 & 11 & 550 & 0.020 & 55056.852 \\
\hline 25 & 5 & 520 & 0.010 & 55298.766 \\
\hline 16 & 11 & 600 & 0.010 & 553330.023 \\
\hline 15 & 9 & 600 & 0.010 & 55462838 \\
\hline 56 & 7 & 520 & 0.020 & 55911.493 \\
\hline
\end{tabular}

Gambar 7. Optimasi Parameter Hidden Layer

Gambar 7 menunjukkan bahwa nilai terkecil dari RMSE adalah 45327.969, dihasilkan pada Windowing Size $=12$, Training Cycles $=550$, dan Learning Rate $=0.010$. Nilai RMSE tersebut mengalami perubahan yang signifikan daripada hasil Optimasi tanpa menggunakan Hidden Layer.

Perhitungan diatas menghasilkan nilai perbedaan antara nilai penjualan dengan nilai prediksi penjualan. Untuk memudahkan visualisasinya, Perbedaan nilai tersebut ditunjukkan dalam bentuk grafik dimana garis warna hijau menunjukkan garis penjualan, sedangkan warna biru menunjukkan garis prediksi penjualan. Grafik perbedaan nilai penjualan dan prediksi penjualan tersebut terlihat pada Gambar 8 .

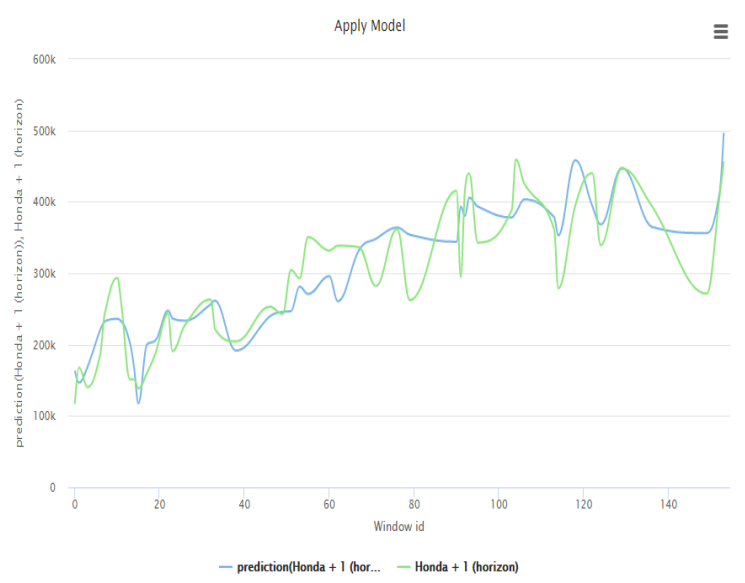

Gambar 8. Grafik Penjualan dan Prediksi Penjualan Sepeda Motor Honda

\section{Kesimpulan dan Saran}

Berdasarkan penelitian yang sudah dilakukan dapat diambil kesimpulan bahwa untuk nilai RMSE (Root Mean Square Error) dengan penerapan Neural Network menggunakan data training 113 record dan data testing 48 record, serta melakukan 90 kali eksperimen pengujian dengan 2 hidden layer menghasilkan rata-rata nilai RMSE (Root Mean Square Error) 45327.969. Penerapan Neural Network dapat diartikan bahwa Neural Network dapat meningkatkan nilai terkecil rata-rata RMSE dalam memprediksi penjualan sepeda motor Honda.

Dengan menggunakan data 12 bulan atau data pertahun, perusahaan dapat memprediksi produksi untuk bulan pertama tahun berikutnya, sehingga permintaan konsumen terhadap barang dapat diketahui oleh pihak perusahaan dan selanjutnya ditindak lanjuti ke bagian produksi. Dari hasil penelitian ini dapat juga disarankan untuk perusahaan, agar data lebih akurat dan lebih banyak, maka rekap penjualan dilakukan tiap satu minggu sekali.

\section{Daftar Pustaka}

[1] Dristyan, F. "PREDIKSI JUMLAH PENJUALAN KREDIT SEPEDA MOTOR MENGGUNAKAN ALGORITMA BACKPROPAGATION." In Seminar Nasional Royal (SENAR) 2018 (pp. 185190).

[2] Fachrie, M., \& Wibowo, A. P. "Jaringan syaraf tiruan untuk memprediksi kinerja satpam." Jurnal Informatika Dan Komputer, 3(1), 46-51, 2018.

[3] Pakaja, F., Naba, A., \& Purwanto. "Peramalan Penjualan Mobil Menggunakan Jaringan Syaraf Tiruan dan Certainty Factor." Jurnal EECCIS, 6(1), 23-28, 2012.

[4] Paruntu, S. A., \& Palandeng, I. D. "ANALISIS RAMALAN PENJUALAN DAN PERSEDIAAN PRODUK SEPEDA MOTOR SUZUKI PADA PT SINAR GALESONG MANDIRI MALALAYANG. EMBA.", 6(4), 2828-2837, 2018.

[5] Sholikhah, M. "FORECASTING TINGKAT PENJUALAN SEPEDA MOTOR SUZUKI PADA CV . ADI MULIA MOTOR DI RENGAT INDRAGIRI HULU DENGAN MENGGUNAKAN METODE TIME SERIES AUTOREGRESSIVE." Universitas Islam Negeri Sultan Syarif Kasim Riau, 2011.

[6] Triatmono, R. "DATA PENJUALAN MOTOR TAHUN 2005 - 2018." Juli, 2019, URL : http://riatmono.info/data-penjualan-tahun2012/data-penjualan-motor-tahun-2005/ 
[7] Wahyuni, A. "PREDIKSI PENJUALAN HYDRATED LIME MENGGUNAKAN METODE NEURAL NETWORK." Jurnal Techno Nusa Mandiri, XIV(1), 27-34, 2017.

[8] Wibisono, G., \& Hermawan, A. "FAKTORFAKTOR PENENTU GEJALA PENYAKIT." Jurnal Aplikasi Sains, Informasi, Elektronika Dan Komputer, 1(1), 1-6., 2019, Retrieved from http://jurnal.unmer.ac.id/index.php/jasiek/article/vie w/3098/pdf

[9] Widyatmoko, H., Honggowibowo, A. S., \& Retnowati, N. C. D. "IMPLEMENTASI DATA MINING UNTUK MERAMALKAN PENJUALAN DI MINIMARKET IDOLA JL PATITAMBAKROMO KM 2 DESA KARANGMULYO RT.08 RW.01 DENGAN METODE TIME SERIES." Jurnal Compiler, 1(2), 29-37, 2012. 